\title{
A derivation and evaluation of the von Bertalanffy equation for describing growth in broilers over time
}

\author{
H. Darmani Kuhi' ${ }^{1}$ E. Kebreab ${ }^{\star}$, S. Lopez ${ }^{2}$ and J. France ${ }^{1}$ \\ ${ }^{\prime}$ The University of Reading, School of Agriculture, Policy and Development \\ Earley Gate, Reading RG6 $6 A R, U K$ \\ ${ }^{2}$ Departamento de Producción Animal, Universidad de León \\ E-24007 León, Spain
}

(Received 11 December 2001; accepted 31 January 2002)

\begin{abstract}
Growth in broilers has been largety described in the literature by the Gompertz equation. In the present study, the von Bertalanffy equation is evaluated with regard to its ability to describe the relationship between body weight and age in chickens, and is compared with its limiting cases: the Gompertz and the Fabens equations. A total of 60 time course profiles with broilers (male and femalc) and with meat and egg strain pullets and hens taken from the literature were used in the analysis. A comparative analysis was carried out based on model behaviour, biologically meaningful parameter estimates and statistical performance. The results of this study based on residual sums of squares values confirm the initial assumption of the possible limitation of the Gompertz equation with its fixed point of inflexion at $1 / \mathrm{c}(=0.368)$ times the final weight. This was especially true for female data profiles. For these data profiles, the point of inflexion of the von Bertalanffy equation, which gave a better fit to the data than the Gompertz and Fabens equations, occurred at 0.296 to 0.357 of the final weights.
\end{abstract}

KEYWORDS: body weight, broilers, growth curve, Fabens, Gompertz, von Bertalanffy

\section{INTRODUCTION}

The Gompertz equation has been the function of choice for describing growth in broilers over time. Wilson (1977) suggested the Gompertz is applicable to avian species. Tzeng and Becker (1981) fitted non-linear and polynomial models to growth

\footnotetext{
' Corresponding author
} 
data on broiler chickens and observed that the Gompertz gave the best fit to live body weight and to carcass weight while the logistic and the von Bertalanffy equations described better the growth of the abdominal fat. However, the latter study was aimed primarily at relating growth in abdominal fat to total carcass fat. After studying how the Gompertz, von Bertalanffy, logistic and Richards fitted growth data, Ricklefs (1985) restricted his attention to the Gompertz model, stating that the fitted parameters are difficult to interpret with the Richards and that the growth of most galliforms, including poultry, conforms closely to the shape of the Gompertz curve. Wiseman and Lewis (1998) employed the Gompertz to survey the patterns of growth of body weight and carcass components, and feed intake accumulation. They reported that the goodness of fit of the Gompertz, as expressed in terms of the proportion of variation in the data accounted for by the equation $\left(\mathrm{R}^{2}\right)$, was very high for major carcass components $(0.99-1.0)$, although the $\mathrm{R}^{2}$ values were considerably lower for minor components.

The Gompertz, however, has the possible limitation of a fixed point of inflexion, which occurs at $1 / \mathrm{e}(=0.368)$ times the final weight (France and Thornley, 1984). Von Bertalanffy (1957) developed a function to describe growth in animals over time. Unlike the Gompertz equation, the von Bertalanffy equation has a flexible (variable) point of inflexion which occurs between 0.296 and 0.368 times the final weight. The elementary mathematical properties and functional form of the lower extreme of the von Bertalanffy (point of inflexion at 0.296 times final weight) were discussed by Fabens (1965). In the present study, the von Bertalanffy equation is evaluated with regard to its ability to describe the relationship between body weight and age in broilers, and is compared with its limiting cases: the Gompertz and the Fabens equations. A mathematical derivation of the von Bertalanffy equation is given, and the 3 equations are applied to 60 time course profiles taken from the literature.

\section{MATERIAL AND METHODS}

\section{Mathematical derivation}

The assumptions are: substrate is non-limiting; growth is the difference between the processes of anabolism and catabolism; anabolism is allometrically related to body weight $W(\mathrm{~g})$; catabolism is linearly related to body weight. Formalizing these assumptions:

$$
\frac{\mathrm{d} W}{\mathrm{~d} t}=\mu W^{b}-\lambda W
$$

where $t$ is time (i.e. age) (d), and $\mu\left(\mathrm{g}^{1-\mathrm{b} / \mathrm{d})}\right.$ and $\lambda(/ \mathrm{d})$ are constants of anabolism and catabolism, respectively. 
Von Bertalanffy (1957) restricted the allometric parameter $b$ to the range $2 / 3 \leq b \leq 1$ on theoretical grounds. Putting $b=1$ in Equation (1) gives exponential growth provided $\mu>\lambda>0$. For lower values of $b$, Equation (1) can be integrated by first writing it as:

$$
\int_{W_{0}}^{W}\left(\frac{1}{W}+\frac{(\mu / \lambda) W^{h-2}}{1-(\mu / \lambda) W^{b-1}}\right) \mathrm{d} W=-\lambda \int_{0}^{t} \mathrm{~d} t
$$

to give the von Bertalanffy equation:

$$
W=\left\{(\mu / \lambda)-\left[(\mu / \lambda)-W_{0}^{1-\mathrm{b}}\right] \mathrm{e}^{-\lambda(1-b) r}\right\}^{1 /(1-b)}
$$

Equation (2) can be expressed in a more compact form by reparameterizing it, Let $W_{f}=(\mu / \lambda)^{1 /(1-b)}, k=\lambda(1-b)$ and $v=(1-\mathrm{b})$, where $0<v \leq 1 / 3 . k$ and $W_{f}$ are positive. Equations (1) to (2) become, respectively:

$$
\begin{gathered}
\frac{\mathrm{d} W}{\mathrm{~d} t}=\frac{k W\left(W_{f}^{v}-W^{v}\right)}{v W^{v}} \\
W=\left[W_{f}^{u}-\left(W_{f}^{v}-W_{0}^{v}\right) \mathrm{e}^{-k t}\right]^{1 / v}
\end{gathered}
$$

At $t=0, W=W_{t}$, the initial weight; for $t \rightarrow \infty, W=W_{f}$, the final weight.

The point of inflexion is found by differentiating Equation (3):

$$
\frac{\mathrm{d}^{2} W}{\mathrm{~d} t^{2}}=\frac{k}{v}\left[(1-v)\left(\frac{W_{f}}{W}\right)^{v}-1\right] \frac{\mathrm{d} W}{\mathrm{~d} t}
$$

Equating this to zero at time $t=t^{*}$ (the inflexion point), therefore either $\mathrm{d} W / \mathrm{d} t=0$, or:

$$
W\left(t=t^{*}\right)=(1-v)^{1 / v} W_{f}
$$

By substituting $W=W\left(t=t^{*}\right)$ from Equation (5) and $t=t^{*}$ into Equation (4) the time to inflexion $t^{*}$ is:

$$
t^{*}=\frac{1}{k} \ln \left[\frac{W_{j}^{v}-W_{0}^{v}}{v W_{j}^{v}}\right]
$$

The expression $(1-v)^{1 / v}$ determines the proportion of the final size at which the inflexion point occurs. When $v=1 / 3,(1-v)^{1 / v}=0.667^{3}=0.296$. When $v=0$, Equation (3) breaks down: but since as $v \rightarrow 0$ the limiting value of $\left[\left(W_{f} / W\right)^{v}-1\right] / v$ is $\ln \left(W_{f} / W\right)$, the growth rate becomes $k W \ln \left(W_{f} / W\right)$, which is the rate appropriate to the Gompertz (France and Thornley, 1984) whose point of inflexion occurs at $1 / \mathrm{e}$ times $W_{f}$. Therefore, the inflexion point for the von Bertalanffy occurs between 0.296 and 0.368 of the final weight. 
The family of curves obtained by varying the parameter $v$ in Equation (4) is sketched in Figure 1. The point of inflexion is able to occur between 0.296 and 0.368 of the final body weight [Equation (5)], as $v$ varies over the range $0<v<1 / 3$.

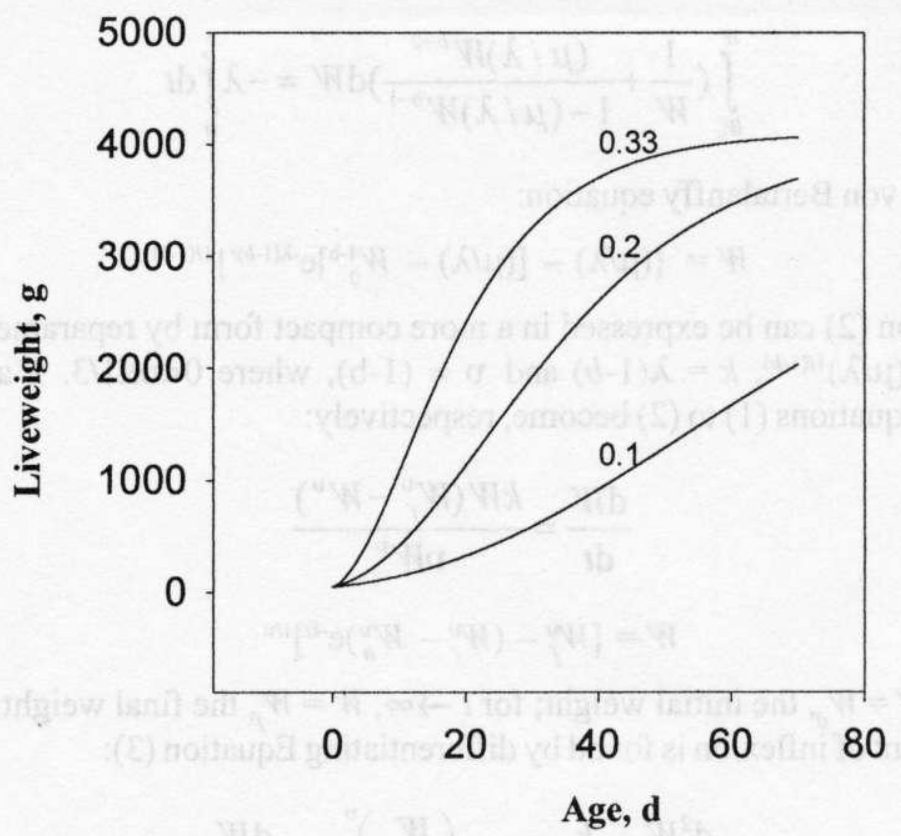

Figure 1. von Bertalanffy equation. The curves describe Equation (4) with $W_{0}=45, W_{f}=4100$, $k=0.24 v$, and for three $\mathrm{v}$-values as given

Models fitted

The growth functions fitted in this study take the form:

Gompertz:

$$
W=\left(W_{f}-W_{0}\right) \exp \left(-\exp \left(-k\left(t-t^{*}\right)\right)\right)
$$

Fabens:

$$
W=\left[\left(W_{f}\right)^{1 / 3}\left(1-A e^{-k t}\right)\right]^{3},
$$

von Bertalanffy:

$$
W=\left[W_{f}^{v}-\left(W_{f}^{v}-W_{0}^{v}\right) \mathrm{e}^{-k t}\right]^{1 / v},
$$


where $t$ is time, $W_{f}$ is the final weight, $W_{0}$ is the initial weight, $t *$ is the time at which the growth rate is at its maximum and $k(/ \mathrm{d}), A$ and $v$ (both dimensionless) are constants. Some properties of these growth equations are shown in Table 1.

TABLE 1

Some properties of the different growth equations

\begin{tabular}{lccc}
\hline $\begin{array}{l}\text { Growth equations } \\
\text { Gompertz }\end{array}$ & $\begin{array}{c}\text { Time to inflexion } \\
(\mathrm{d} W / \mathrm{d} t)\end{array}$ & $\begin{array}{c}\text { Weight at inflexion } \\
\left(W^{*}\right)\end{array}$ \\
\hline$k W \ln \left(\frac{W_{f}}{W}\right)$ & $\frac{1}{k}\left[\ln \left(\ln \left(\frac{W_{f}-W_{0}}{W_{0}}\right)\right]\right.$ & $0.368 W_{f}$ \\
Fabens & $k W \ln \left[\left(\frac{W_{f}}{W}\right)^{1 / 3}-1\right]$ & {$\left[\frac{\ln A+\ln 3}{k}\right]$} & $0.296 W_{f}$ \\
von Bertalanffy & $\mu W^{1 \cdot \mathrm{v} t}-\lambda W$ & $\frac{1}{k} \ln \left[\frac{W_{f}^{\prime \prime}-W_{0}^{\prime \prime}}{v W_{f}^{\prime \prime}}\right]$ & $(1-v)^{1 / 0} W_{f}$ \\
\hline
\end{tabular}

\section{Experimental data}

A total of 60 time course profiles with broilers (male and female) and with meat and egg strain pullets and hens, were taken from the literature and used in this study. Details of the sources, growth phases, sex, strain and some dietary characterizations of the experimental data are given in Table 2 .

\section{Statistical procedures}

The growth functions were fitted to the data using the non-linear fitting procedures of Sigmaplot (SPSS, 1998). A number of statistical analyses were used to evaluate the general goodness-of-fit of each model. The $\mathrm{r}^{2}$ (adjusted $\mathrm{R}^{2}$ ) was calculated as $1-\frac{\operatorname{RSS} /(n-p)}{S_{r}^{2}(n-1)}$, where RSS (residual sum of squares) is a measure of the variability in liveweight remaining after the age variable (the regressor variable) has been considered, $n$ is number of data points, $p$ is number of parameters included in the model and $S_{y}^{2}$ (the total variation of the $y$-variable) is a measure of the variability in liveweight without considering the effect of the age variable. The RSS was used to compare two different models when fitted to the data. The statistical significance between models in terms of the goodness-of-fit was assessed using an F-test described by Motulsky and Ransnas (1987) for comparing two models with 
TABLE 2

Data sources used in the study

\begin{tabular}{|c|c|c|c|c|c|}
\hline \multirow{2}{*}{ Source } & \multirow{2}{*}{$\begin{array}{l}\text { Growth } \\
\text { phase } \\
\mathrm{d}\end{array}$} & \multicolumn{2}{|c|}{ Sex' } & \multirow{2}{*}{ Strain } & \multirow{2}{*}{ Considerations } \\
\hline & & M & $\mathrm{F}$ & & \\
\hline Ajang el al. (1993) & $7-48$ & 6 & 6 & Broilers & $\begin{array}{l}\text { Different dietary } \\
\text { protein content }\end{array}$ \\
\hline Grey et al. (1982) & $21-364$ & 1 & 1 & Ross 1 & - \\
\hline Hancock et al. (1995) & $0-77$ & 6 & 6 & $\begin{array}{l}\text { Hubbard, Hybro, } \\
\text { Ross } 708,788,608 \\
\text { and } 688\end{array}$ & - \\
\hline Lceson and Summers (1980) & $0-70$ & 1 & 1 & Broilers & - \\
\hline $\operatorname{NRC}(1994)^{2}$ & $7-70$ & 1 & 1 & Broilers & - \\
\hline Plavink and Hurwitz (1983) & $7-70$ & 1 & 1 & White Rock & - \\
\hline Waldroup et al. (1976) & $7-63$ & 6 & 6 & Broilers & $\begin{array}{l}\text { Different starter } \\
\text { and finisher diets }\end{array}$ \\
\hline Wiseman and Lewis (1998) & $0-70$ & 5 & 0 & Ross & $\begin{array}{l}\text { Different starter } \\
\text { and finisher diets }\end{array}$ \\
\hline Altman and Dittmer (1964) & $0-140$ & 1 & 1 & New Hampshire & - \\
\hline Almman and Dittmer (1964) & $0-140$ & 1 & 1 & Cornish & - \\
\hline Altman and Dittmer (1964) & $0-140$ & 0 & 1 & White Leghorn & - \\
\hline Leeson and Summers (1997) & $0-154$ & 0 & 1 & Egg strain & - \\
\hline Leeson and Sumners (1997) & $0-56$ & 3 & 0 & Broilers & - \\
\hline Leeson and Summers (1997) & $0-56$ & 1 & 0 & Broilers & - \\
\hline Leeson and Summers (1997) & $0-84$ & 1 & 0 & Broilers & - \\
\hline
\end{tabular}

${ }^{1} \mathrm{M}=$ male, and $\mathrm{F}=\mathrm{fcmale}$; the numbers, under $\mathrm{M}$ and $\mathrm{F}$ subheadings, refer to the number of data profiles from a specific data source

2 these data are not directly experimental but were produced by compositing and smoothing data from various resources

the same or a different number of parameters. To compare models with the same parameters, the following equation was used:

$$
\mathrm{F}=\frac{\mathrm{SS}_{1}}{\mathrm{SS}_{2}}
$$

and for models with different number of parameters the equation used was:

$$
F=\frac{\left(\mathrm{SS}_{1}-\mathrm{SS}_{2}\right) /\left(\mathrm{df}_{2}-\mathrm{df}_{1}\right)}{\mathrm{SS}_{2} / \mathrm{df}_{2}}
$$

where SS is the sums of squares and df is degrees of freedom. 


\section{RESULTS}

The applicability of the different growth functions was examined by fitting them to the different time course profiles. The results indicated that in all cases, the models could be fitted to the females and males growth data without difficulty by non-linear regression. Figures 2 and 3 give a sample of the fitted curves, showing three different time course profiles for females and males, respectively, fitted using
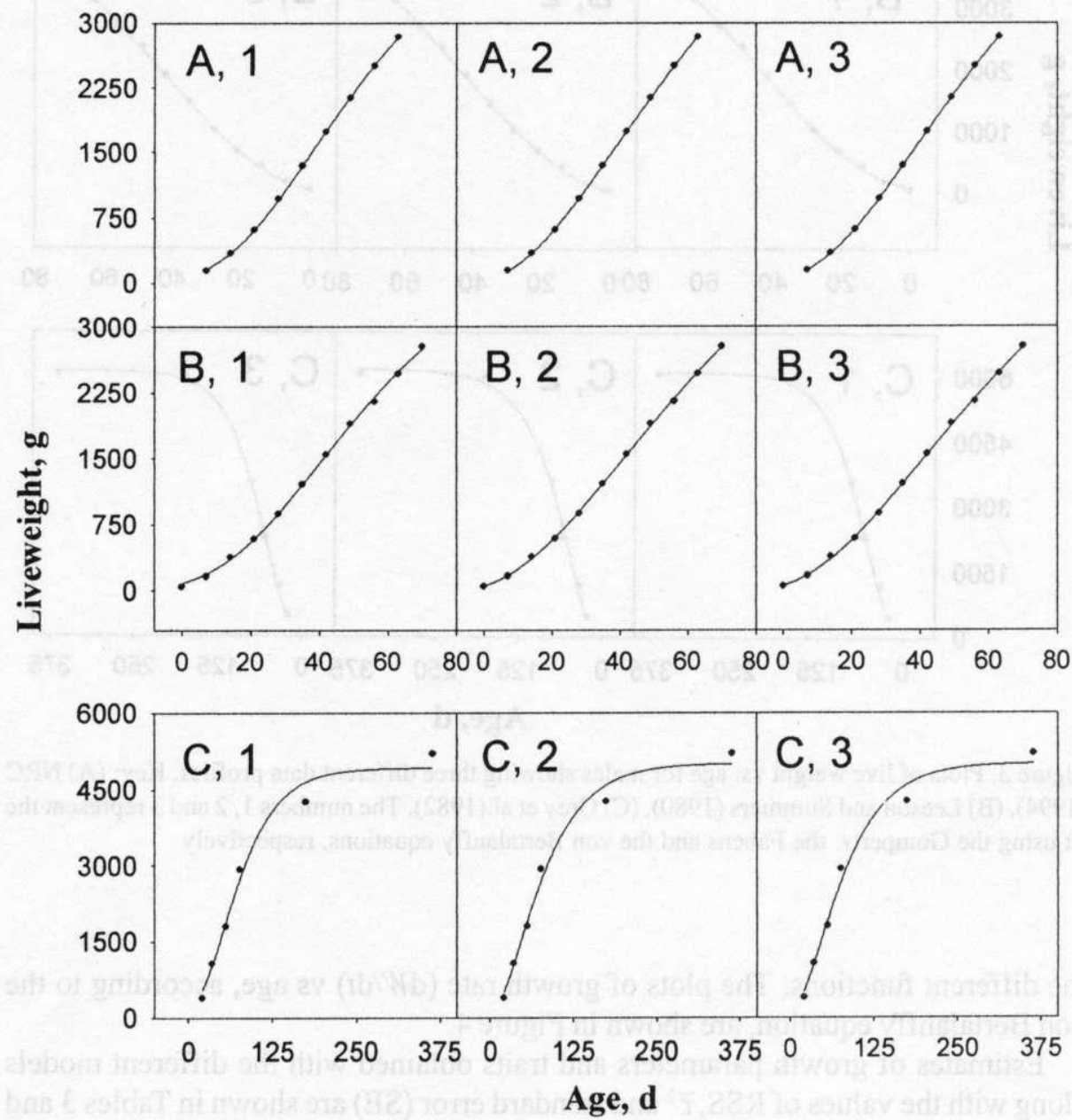

Figure 2. Plots of live weight vs. age for females showing three different data profiles. Key: (A) NRC (1994), (B) Leeson and Summers (1980), (C) Grey et al.(1982). The numbers 1, 2 and 3 represent the fit using the Gompertz, the Fabens and the von Bertalanffy equations, respectively 

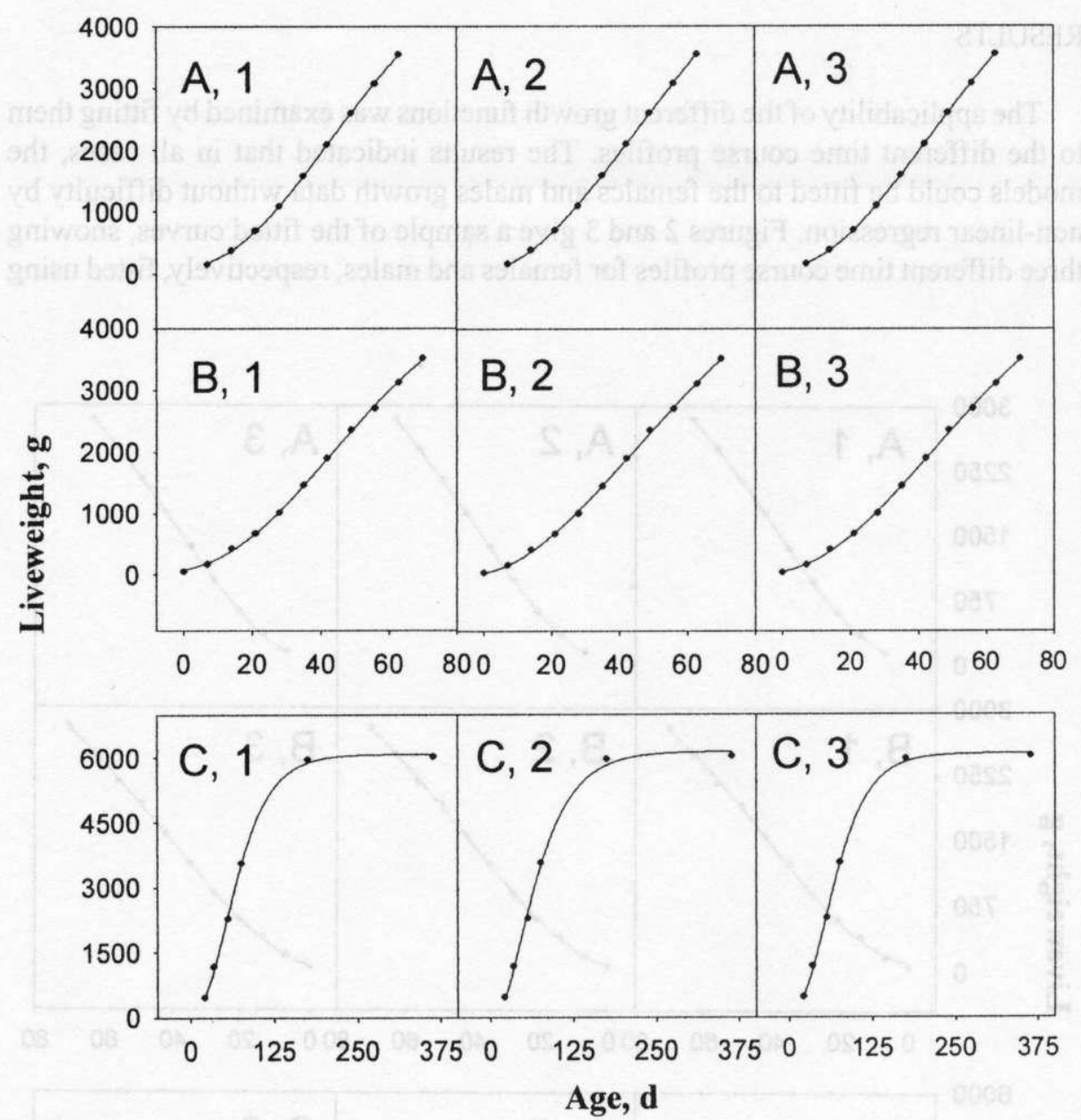

Figure 3. Plots of live weight vs. age for males showing three different data profiles. Key: (A) NRC (1994), (B) Leeson and Summers (1980), (C) Grey et al.(1982). The numbers 1, 2 and 3 represent the fit using the Gompertz, the Fabens and the von Bertalanffy equations, respectively

the different functions. The plots of growth rate $(\mathrm{d} W / \mathrm{d} t)$ vs age, according to the von Bertalanffy equation, are shown in Figure 4.

Estimates of growth parameters and traits obtained with the different models along with the values of RSS, $\vec{r}^{2}$ and standard error (SE) are shown in Tables 3 and 4 for females and in Tables 5 and 6 for males. Although the analyses were carried out for all time course profiles (both male and female data), limitations on space prevent the presentation of the results for all of the profiles through Tables 3 to 6 . 


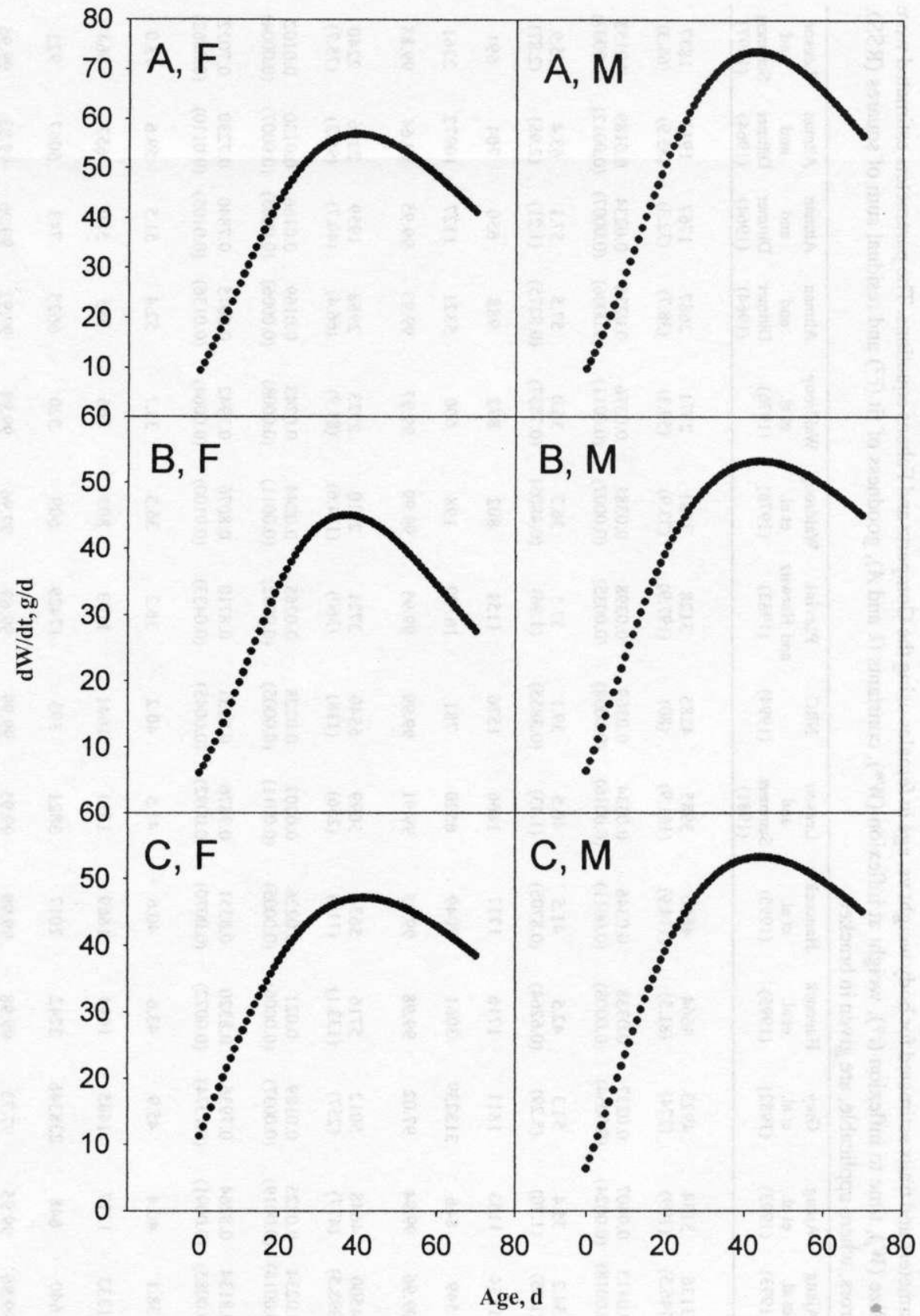

Figure 4. Plots of the estimated values of growth rate, $\mathrm{d} W / \mathrm{d} t, v s$. age for the von Bertalanffy equation using three different data profiles. Key: (A) NRC (1994), (B) Plavink and Hurwitz (1983), (C) Leeson and Summers (1980), (F) Female, and (M) Male 
당

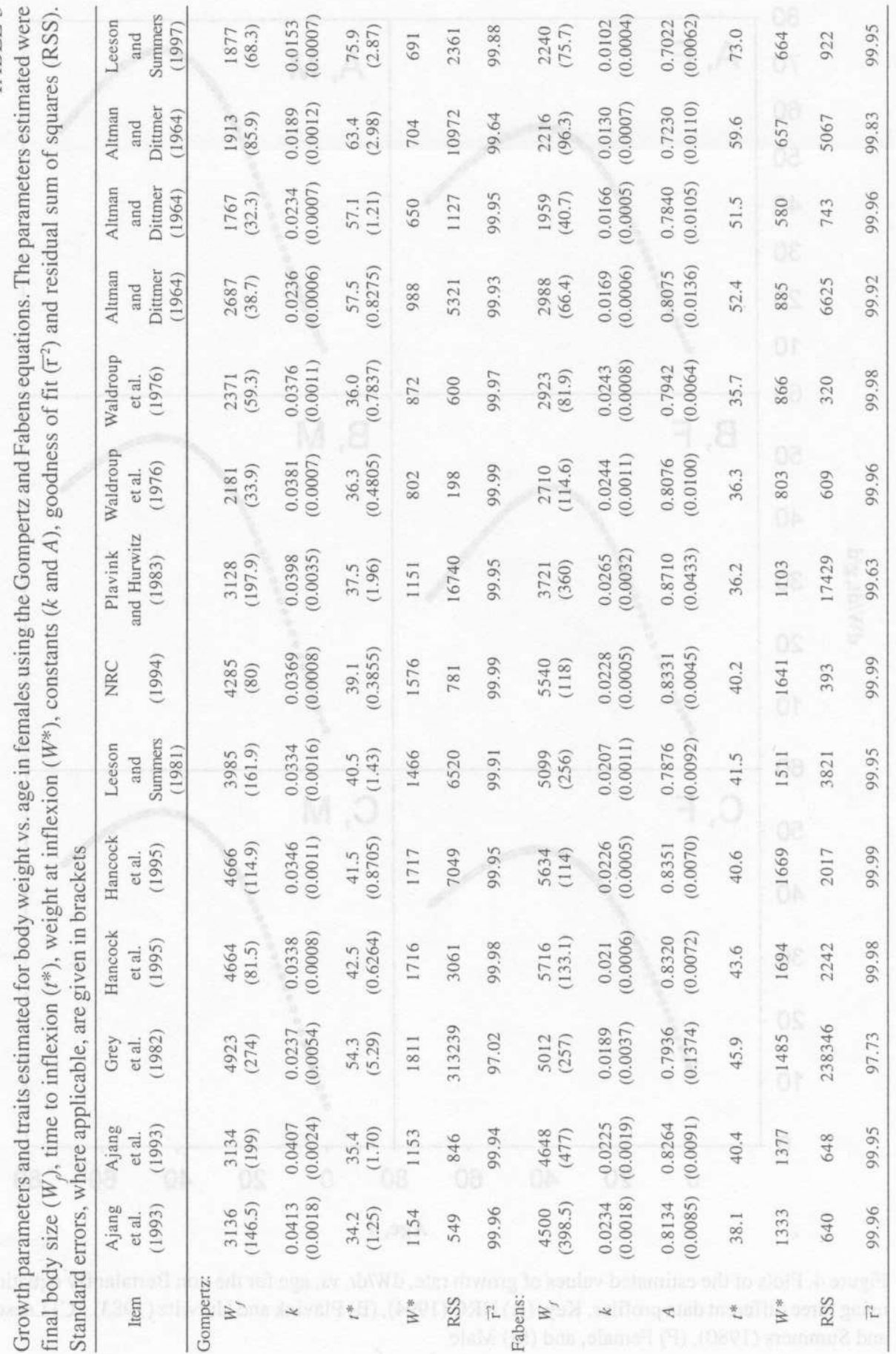




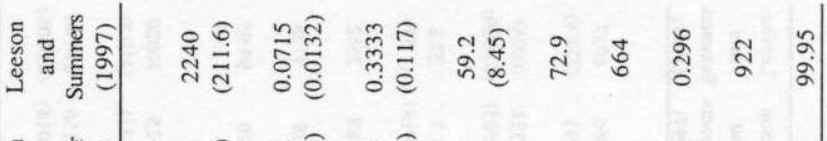

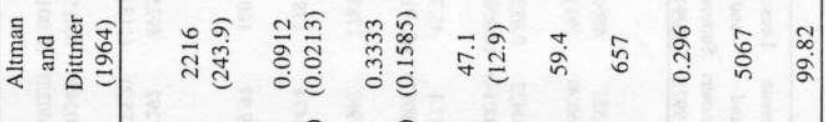
है

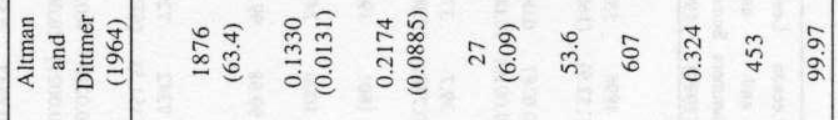
可

递

댕

苋

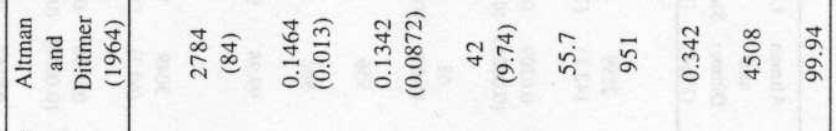

है

도

ัํำ

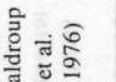

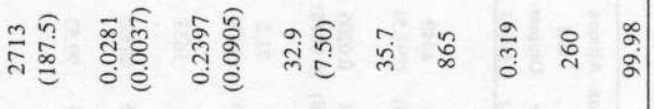

幽

产 สं

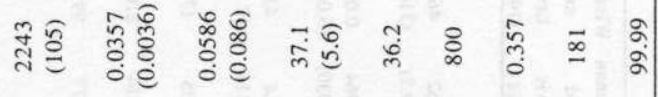

एँ

ธิ

$\cong$

.

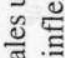

密 娄

.5 .

品 3

度焉

댕ำ

3 造

즐 율

$\therefore$.

흥

चु

है

㻤

然

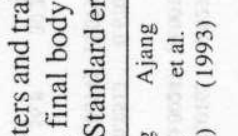

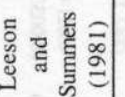

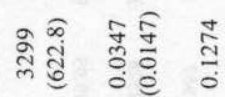

言

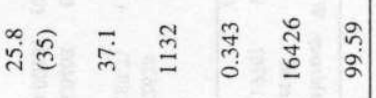

产高

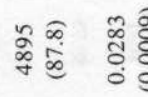

융

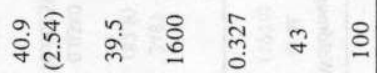

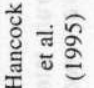

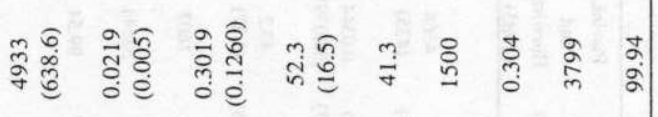

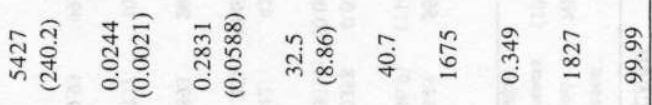

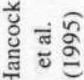

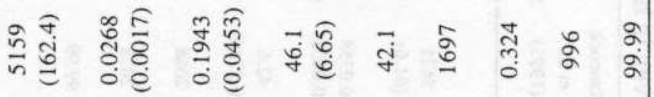

ปें สं สิ

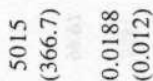

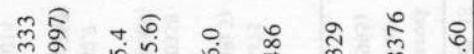

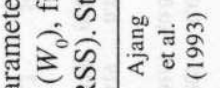

हू $\approx$

全

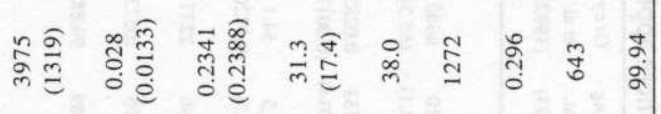

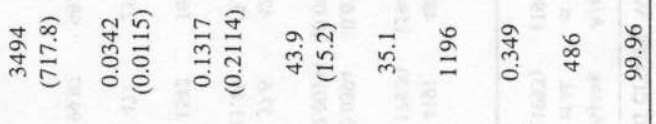




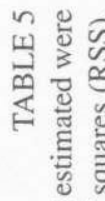

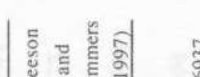

ๆ $\overline{0}$ 定

$\infty E$

กั

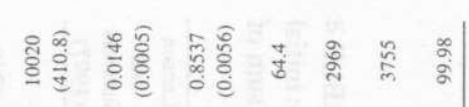

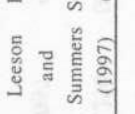

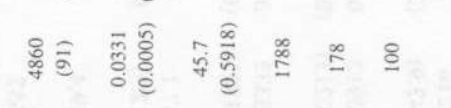

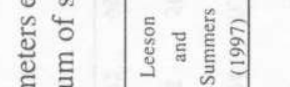

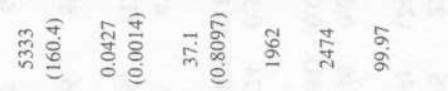

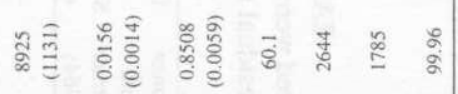

究璦

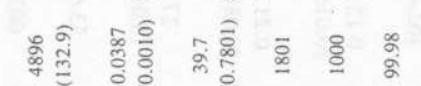

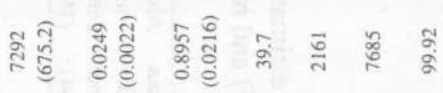

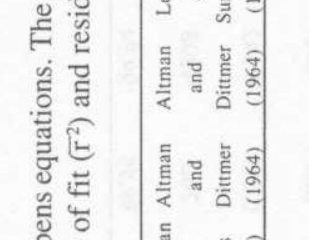

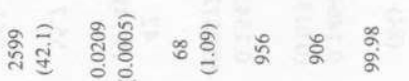

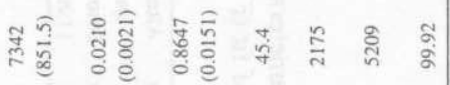

도 흥

ก

政

हू

$\underset{0}{ \pm}$

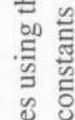

宽

.$\stackrel{5}{\Xi}$

品. ำ

$\dot{s} \vec{e}$

…

क्षे

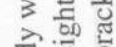

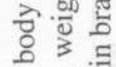

实宁

密

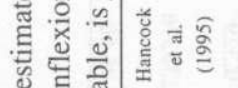

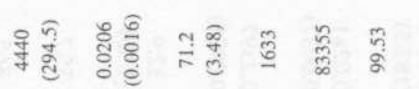

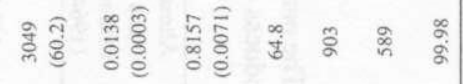

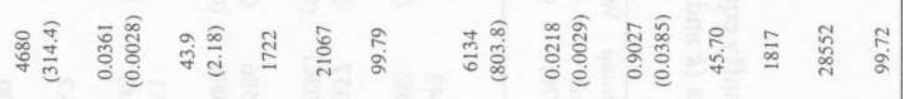

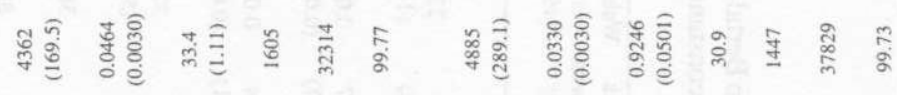

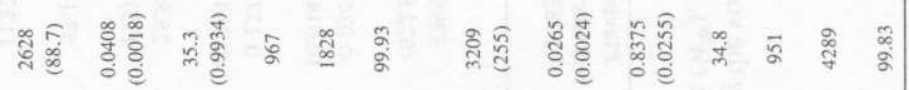

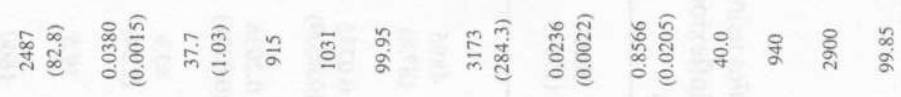

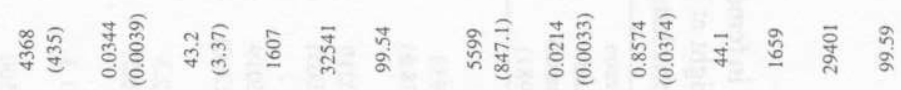

容委

\%

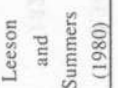

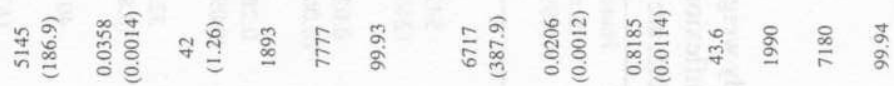

స్ర

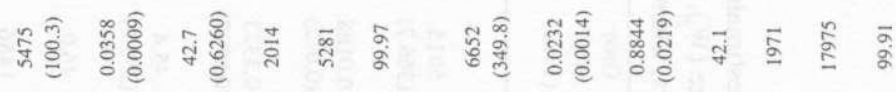

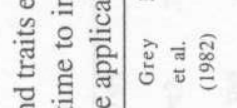

空

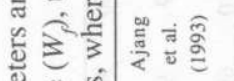

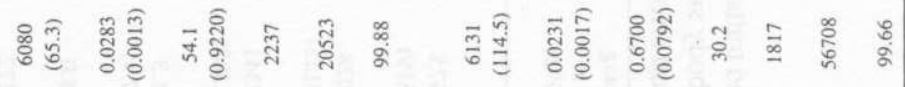

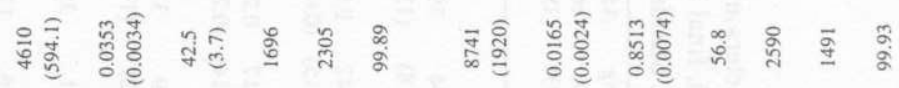

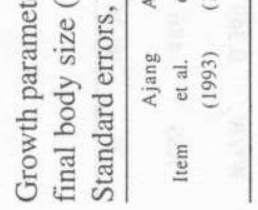

$\overline{\frac{a}{7}}$

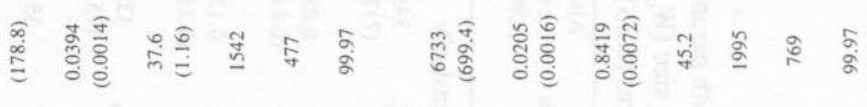
产 $2 \quad y$ in 


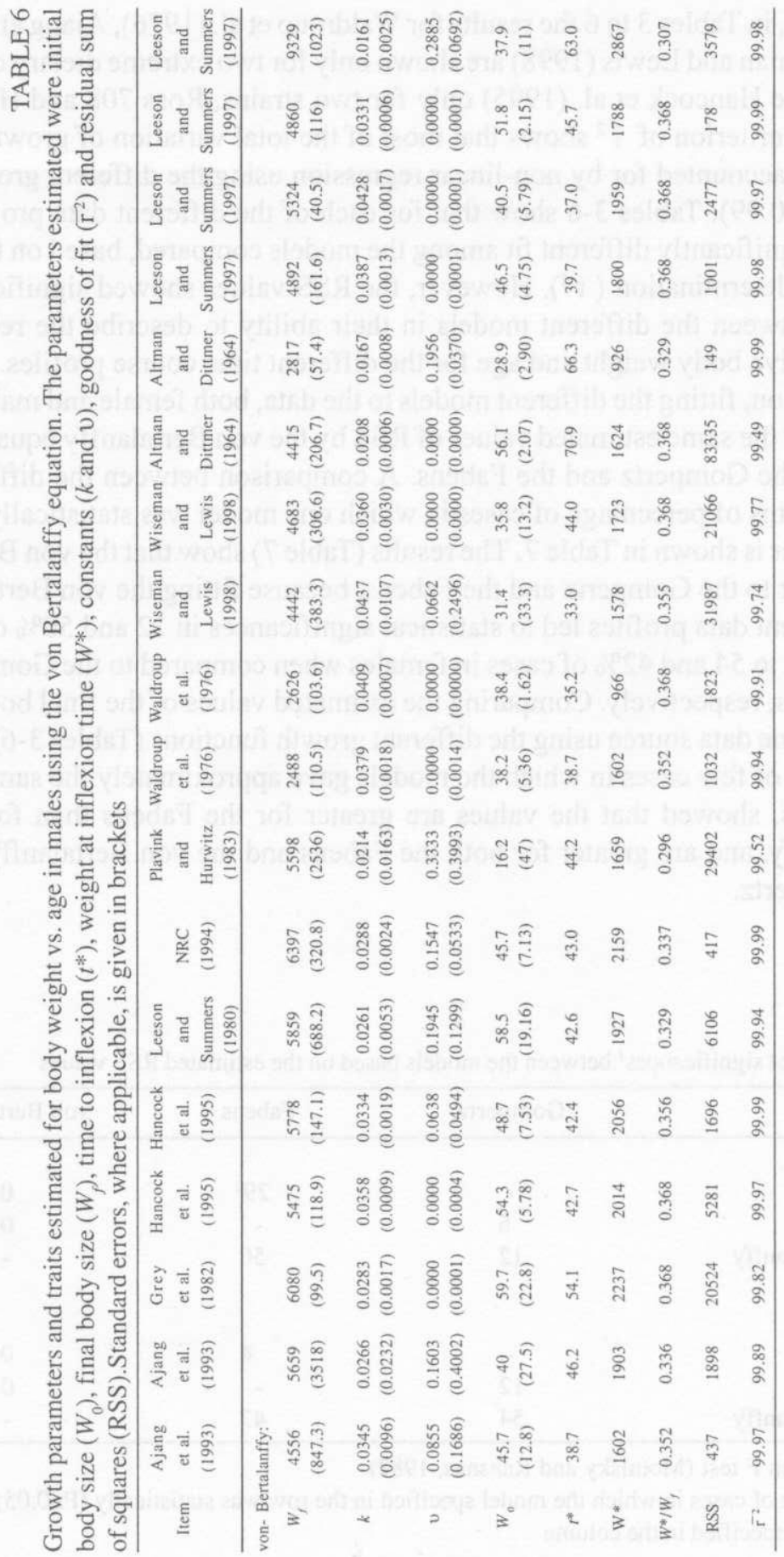


Therefore, in Tables 3 to 6 the results for Waldroup et al. (1976), Ajang et al. (1993) and Wiseman and Lewis (1998) are shown only for two extreme dietary conditions and for the Hancock et al. (1995) only for two strains, Ross 708 and Hybro. The statistical criterion of $\mathrm{r}^{2}$ shows that most of the total variation of growth in body weight is accounted for by non-linear regression using the different growth functions $\left(\overline{\mathrm{r}}^{2}>0.99\right)$. Tables $3-6$ show that for each of the different data profiles there was no significantly different fit among the models compared, based on the coefficients of determination $\left(\mathrm{r}^{2}\right)$. However, the RSS values showed significant differences between the different models in their ability to describe the relationship between live body weight and age for the different time course profiles. Based on this criterion, fitting the different models to the data, both female and male, led to a smaller or the same estimated values of RSS by the von Bertalanffy equation compared to the Gompertz and the Fabens. A comparison between the different models in terms of percentage of cases in which one model was statistically superior to the other is shown in Table 7. The results (Table 7) show that the von Bertalanffy is superior to the Gompertz and the Fabens, because fitting the von Bertalanffy to the different data profiles led to statistical significances in 12 and $50 \%$ of cases in males and to 54 and $42 \%$ of cases in females when compared to the Gompertz and the Fabens, respectively. Comparing the estimated values of the final body weight for the same data source using the different growth functions (Tables 3-6), with the exception of few cases in which the models gave approximately the same estimated values, showed that the values are greater for the Fabens than for the von Bertalanffy, and are greater for both the Fabens and the von Bertalanffy than for the Gompertz.

TABLE 7

The statistical significances ${ }^{\prime}$ betwecn the models based on the estimated RSS values

\begin{tabular}{lccc}
\hline Models & Gompertz & Fabens & von Bertalanffy \\
\hline Males & & & \\
Gompertz & - & - & 0 \\
Fabens & 6 & 50 & 0 \\
von Bertalanffy & 12 & -
\end{tabular}

Females

\begin{tabular}{|c|c|c|c|}
\hline Gompertz & - & 4 & 0 \\
\hline Fabens & 12 & - & 0 \\
\hline von Bertalanffy & 54 & 42 & - \\
\hline
\end{tabular}


Considering the growth rate of the von Bertalanffy equation in males and females (Figure 4 ), it is evident that values for the maximum gain in weight $(\mathrm{g} / \mathrm{d})$, which occur at the time to inflexion, are greater for males than for females and that the growth rate will approach zero as the birds reach maturity.

\section{DISCUSSION}

The Gompertz equation has been the function of choice for describing growth in broilers in the literature. The Gompertz, however, has the possible limitation of a fixed point of inflexion. Therefore, in the present study, the von Bertalanffy equation (a flexible growth function) was evaluated with regard to its ability to describe the relationship between body weight and age in broilers, and was compared to its limiting cases: the Gompertz and the Fabens equations.

The purpose of curve fitting is to describe the course of mass increase with age by simple equations with few parameters, which in the most useful models are biologically interpretable (Ricklefs, 1985). However, there is no single, simple method to evaluate similarities and differences between non-linear models and to recommend which model should be used (Motulsky and Ransnas, 1987). Hence, the comparison of the models in this study was carried out according to three criteria: model behaviour when fitting the curves using non-linear regression, statistical performance, and comparison of biologically meaningful parameters estimated by each model.

The results of this study indicated that the different data profiles both male and female can be described by the different growth functions with a very high degree of accuracy $\left(\mathrm{r}^{2}>0.99\right)$. However, in spite of this similarity there are some important differences between the growth functions. Although, fitting the Gompertz and the Fabens to the different data profiles led to statistically very significant parameters (parameters with significantly lower standard errors at $P<0.0001$ ) in all cases, fitting the von Bertalanffy to the same data profiles resulted in $91 \%, 76 \%, 12 \%$ and $85 \%$ significant parameters in males and to $92 \%, 81 \%, 35 \%$ and $77 \%$ significant parameters in females for $W_{f}, W_{0}, v$ and $k$, respectively. But, since the estimated standard error of the parameters are based on linearizing assumptions and will always underestimate the true uncertainty of any nonlinear equation, these values should not be taken into account too seriously (Motulsky and Ransnas, 1987). With the logistic (results not shown), for example, the RSS values and biologically meaningful parameters did not suggest a suitable fit to the different data profiles, but fitting the equation in all cases led to statistically very significant parameter estimates. Comparisons based on the statistical significances between the estimated RSS values (Table 7) indicated that there are significant differences between the models. Here the really interesting choice lies between the generalized von Berta- 
lanffy model and its special cases, the Gompertz and the Fabens. Based on this criterion and dependent on the sex (for female more than male data profiles), the von Bertalanffy showed superiority to the Gompertz and the Fabens. The results, especially for females, show the point of inflexion based on the von Bertalanffy equation occurred between 0.296 and 0.357 of final weight, confirming the initial assumption of the possible limitation of a fixed point of inflexion with the Gompertz equation.

In conclusion, the results of this study confirmed our initial reservation about the adoption a single growth function with a fixed point of inflexion for describing the relationship between live body weight and age in broilers. Therefore, consideration of flexible growth functions such as von Bertalanffy equation as an alternative to the Gompertz is recommended. This recommendation is based on model testing and evaluation, an essential part of the model development process.

\section{REFERENCES}

Ajang O.A., Prijono S., Smit W.K., 1993. Effect of dietary protein content on growth and body composition of fast and slow feathering broiler chickens. Brit. Poultry Sci. 34, 73-91

Altman P.L., Dittmer D.S., 1964. Biology Data Book. Federation on American Societies for Experimental Biology. Washington, DC

Fabens A.J., 1965. Properties and fitting of the von Bertalanffy growth curve. Growth 29, 265-289

France J., Thornley J.H.M., 1984. Mathematical Models in Agriculture. Butterworth, London

Grcy T.C., Robinson D., Jones J., 1982. Effect of age and sex on the eviscerated yield, muscle and edible offal of a commercial broiler strain. Brit. Poultry Sci. 23, 289-298

Hancock C.E., Bradford G.D., Emmans G.C., Gous R.M., 1995. The evaluation of the growth parameters of six strains of commercial broiler chickens. Brit. Poultry Sci. 36, 247-264

Leeson S., Summers J.D., 1980. Production and carcass characteristics of the broiler chicken. Poultry Sci. $59,786-798$

Leeson S., Summers J.D., 1997. Commercial Poultry Nutrition $2^{\text {nd }}$ Edition. University Books, Guelph, Ontario (Canada)

Motulsky H.J., Ransnas L.A., 1987. Fitting curves to data using nonlinear regression: A practical and nonmathematical review. FASEB J. 1, 365-374

National Rescarch Council, 1994. Nutrient Requirements of Poultry. $9^{\text {th }}$ revised Edition. National Academy Press, Washington, DC

Plavink I., Hurwitz S., 1983. Organ weight and body composition in chicken as related to the energy and amino acid requirements: Effects of strain, sex and age. Poultry Sci. 62,152-163

Ricklefs R.E., 1985. Modification of growth and devclopment of muscles in poultry. Poultry Sci. 64,1563-1576

SPSS, 1998. SigmaPlot 5.0 User's Guide. SPSS Inc., Chicago, IL

Tzeng R.Y., Becker W.A., 1981. Growth patterns of body and abdominal fat weights in male broiler chickens. Poultry Sci. 60, 1101-1106

Von Bertalanffy L., 1957. Quantitative laws for metabolism and growth. Quart. Rev. Biol. 32, 217-231

Waldroup P.W., Mitchell R.J., Payne J.R., Johnson Z.B., 1976. Characterization of the response of broiler chickens to diets varying in nutrient density content. Poultry Sci. 55, 130-145 
Wilson B.J., 1977. Growth curves: their analysis and use. In: K.N. Boorman, B.J. Wilson (Editors). Growth and Poultry Meat Production. British Poultry Science Ltd., Edinbrough, pp. 89-115

Wiseman J., Lewis C.E., 1998. Influence of dietary energy and nutrient concentration on the growth of body weight and of carcass components of broiler chickens. J. Agr. Sci. 131, 361-371

\section{STRESZCZENIE}

\section{Zastosowanie równania von Bertalanffy'ego do opisu wzrostu brojlerów}

Przyrosty masy ciała brojlerów sa opisywane w literaturze zazwyczaj przy pomocy równania (krzywej) Gompertza. Przedmiotem przeprowadzonych badań jest ocena przydatności równania von Bertalanffy'ego do opisu zalcżności miçdzy masą ciała i wiekiem brojlerów w porównaniu z innymi metodami (równania Gompertza i Fabensa). Analizą objęto 60 zcstawów danych pochodzących z różnych populacji, takich jak; brojlery (obu płci), rody mięsne i nieśne. Anatiza porównawcza opierała się na kryteriach adekwatności modelu - wielkości estymatorów wybranych parametrów (wariancji błędu i współczynnika determinacji). Uzyskane wyniki, opierające się na analizie sum kwadratów dla błędu, potwierdzają wcześniejsze przypuszczenia dotyczące możliwości apłikacyjnych równania (krzywej) Gompertza dla iloczynu ustalonego punktu nachylenia $(1 / \mathrm{e}=0.368)$ i masy ciała. Tendencja ta jest szczególnic widoczna w przypadku osobników żeńskich. W przypadku analizowanych zestawów danych, punkt nachylenia w równaniu von Bertalanffy'ego osiagną̧ł większą efektywność, od 0.296 do 0.357 , niż w przypadku równań Gompertza i Fabensa. 